\title{
A dynamic model for assessing nonproduction (labor) losses of an enterprise
}

\author{
Larisa A. Ismagilova \\ Professor, Head of Department of Business Economics \\ Ufa State Aviation Technical University \\ Address: 12, Karl Marx Street, Ufa, 450000, Russian Federation \\ E-mail: Ismagilova_ugatu@mail.ru
}

\section{Marina V. Frants}

Associate Professor, Department of Business Economics

Ufa State Aviation Technical University

Address: 12, Karl Marx Street, Ufa, 450000, Russian Federation

E-mail:tan-Marina@mail.ru

\section{Murat B. Kulmukhametov}

Doctoral Student, Institute of Social and Economic Research

Ufa Scientific Center of Russian Academy of Sciences

Address: 71, October Prospect, Ufa, 450000, Russian Federation

E-mail: murat.kulmuhametov@gmail.com

\begin{abstract}
The article deals with the problem of an enterprise's human resource management. An enterprise's human resources are described as a dynamic object of management with a great number of parameters specifying various aspects of its condition. The traditional techniques of human resources analysis are based, firstly, on retrospective analysis of data, and secondly, they take different aspects isolated from each other. The proposed managerial decisions are assessed from the point of view of their impact on separate parameters, but their synergetic effect is not assessed. These drawbacks may be eliminated through application of dynamic modelling including cognitive and flow modeling.

Cognitive modeling identifies mechanisms responsible for system reaction on managerial and disturbing influences. A cognitive map of the problem of human resources management was made which includes lots of feedback loops, both reinforcing and balancing. This means, the control object is characterized by nonlinear dynamics and counterintuitive behavior. These features make it difficult to predict object reaction on managerial and disturbing influences.

Within the overall issue of human resources management, this work reviews its particular aspect - the analysis of company's nonproduction losses due to temporary disability of employees. The temporary disability of an employee is understood as his/her temporary inability to perform job duties because of health condition of either himself/herself or his/her family members. The temporary disability is considered to be partially controlled by the enterprise. A flow model is elaborated for assessing a company's nonproduction losses caused by temporary disability of its employees, which can be used to optimize human resources management costs of an enterprise from the perspective of the cost-benefit ratio.
\end{abstract}

Key words: human resources management, dynamic modeling, cognitive map, flow modeling.

Citation: Ismagilova L.A., Frants M.V., Kulmukhametov M.B. (2017) A dynamic model for assessing nonproduction (labor) losses of an enterprise. Business Informatics, no. 1 (39), pp. 14-24.

DOI: 10.17323/1998-0663.2017.1.14.24. 


\section{Introduction}

$\mathrm{T}$ The importance of any company's human resources as the carrier and driver of innovations rises strongly in the knowledge-driven economy. This is why the task of efficiently managing the human resources becomes more and more urgent nowadays. This, in particular, explains the significant number of scientific publications on the subject matter.

Labor productivity is traditionally considered to be a key integral parameter describing the efficiency of human resources management. Quite a lot of scientific articles deal with comparative analysis of labor productivity in the Russian Federation and other countries of the world. Structural transformation and its implications for productivity growth in the BRICS countries from the 1980s onwards is studied in [1]. It is shown that relocation of labor across sectors is contributing to aggregative productivity growth in Russia. Lots of studies indicate that the Russia is lagging behind the developed countries in terms of the labor productivity [2-5]. According to the International Labor Organization, in 2010 Russia was the 60 -th in labor productivity worldwide; per capita (employed population) output came to US\$18,259 in this country, while the leading countries - the US, Hong-Kong and Ireland - recorded US $\$ 68,126$, US\$ 61,383 and US\$ 57,473 respectively [4]. From these numbers, we see that labor productivity in Russia was approximately three times lower than in the leading countries. Similar results have been obtained for the year 2012 when the labor productivity parameter (US\$/manhour) was calculated for Russia and the world's developed countries [5]. As per the calculations therein, Norway led in this parameter, with labor productivity at US\$ 88.08/manhour, while close results were shown by the US, Germany, France - US\$ 63.4, $62.16,63.46 /$ manhour respectively. In Russia this parameter reached just US\$24.97/manhour. It is noteworthy that the Russian "worktime fund (hour/man per year)" parameter is one of the highest $[5,6]$. In order to identify the reasons of low labor productivity in the RF and to search for tools to raise it, analysis has been done on the factors determining employees' motivation for productive labor. Special attention is paid to such factors as the situation in the labor market and the amount/differentiation of wages. It is noted that, given the low level of unemployment in the RF, shortage of personnel (both absolute and structural) is a burning issue. Low wages in general and very high differentiation of wages is another demotivating factor [5]. A systemic analysis of labor productivity in the RF as a whole and in its individual sectors has been done in [7]. This publica- tion explains the low labor productivity in the RF with the following reasons: inefficient organization of labor; nontransparent and excessive regulation; obsolete facilities and methods of manufacturing; rare use of the complex approach to planning territorial development; lack of professional skills; underdevelopment of the financial system; absence of incentives to raise labor productivity; structural peculiarities of the economy. We note that in that work the factor of inefficient labor organization in Russian companies is asserted as a most essential one, with its weight ranging sector-wise between $30 \%$ and $80 \%$. All of this determines the urgency of research in the management of companies' human resources.

An enterprise's human resources management includes an entire set of tasks, such as planning the need for skilled labor, search and employment of personnel, its adaptation, training and reskilling, arrangement of employees' working conditions and health care, setting up the system of material and moral incentives, etc.

The main task of human resources management is the steady supply of skilled personnel with such qualitative and quantitative characteristics as required for the company to achieve its goals with minimal staff costs. Therefore, any managerial decision in personnel development should be optimized and substantiated from the perspective of the cost-benefit ratio [8].

\section{Task definition}

An enterprises human resources may be described as a dynamic object of management with a great number of parameters specifying various aspects of its condition, such as availability of human resources in a particular time and situation, turnover of staff, reasonable structure of personnel in terms of age, gender, education and qualification, labor productivity and its impact on the enterprise's profitability, payroll rate, accident frequency rate, workplace discipline, employees' satisfaction level, employees' innovation activity, etc. It is important to note that the afore mentioned aspects are largely interconnected and interdependent and they determine organizationally the management objectives of the company's strategic development.

The traditional techniques of human resources analysis are based, as a rule, on retrospective analysis of data, and if they consider the aforementioned aspects over a period of time, they take them isolated from each other [9]. The proposed managerial decisions are assessed from the point of view of their impact on separate parameters, but their synergetic effect is not assessed. These drawbacks may be eliminated through application 
of dynamic modeling of the human resources analysis and the selection of efficient managerial decisions in the area of organizational control at an enterprise.

The system dynamics method is based on the idea that the complexity, unpredictability, counter-intuitivity of compound object dynamics is caused by multiple ties between its elements and their mutual influence. Hence, to forecast and control a compound object one needs to identify and describe those ties, first on a qualitative level by way of developing a cognitive map $[10,11]$ and then quantitatively, by way of developing a flow model [12, 13].

This work tackles the following problems:

1. Development of an enterprise's human resources management cognitive map to describe mutual influence of the features specifying various aspects of human resources status;

2. Development of a flow model to assess enterprise nonproduction losses due to the staff temporary disability.

3. Substantiation of managerial decisions on dynamic correction of nonproduction losses from temporary disability of employees.

\section{Proposed approach}

Figure 1 shows an enterprise's human resource management cognitive map allowing us to describe interrelations between the aspects noted above.

The cognitive map analysis demonstrates that the parameters specifying human resources of an enterprise are connected with a significant number of direct and feedback links which form several feedback loops, both amplifying and counterbalancing ones. The given cognitive map shows how tough it is to forecast the "reaction" of such system to any management action. As an example, let us assume the management of a company looks into raising the salary rate. Lower profitability of the company seems to be the most evident consequence of this, since the payroll is a component of costs. However, according to the cognitive diagram, a salary increase will also make possible lower staff turnover, a reasonable structure in terms of age, gender, education and qualification, higher productivity of labor and, through all of that, better profitability. Thus, on the one hand, a salary increase impairs profitability and, on the other hand, improves it.

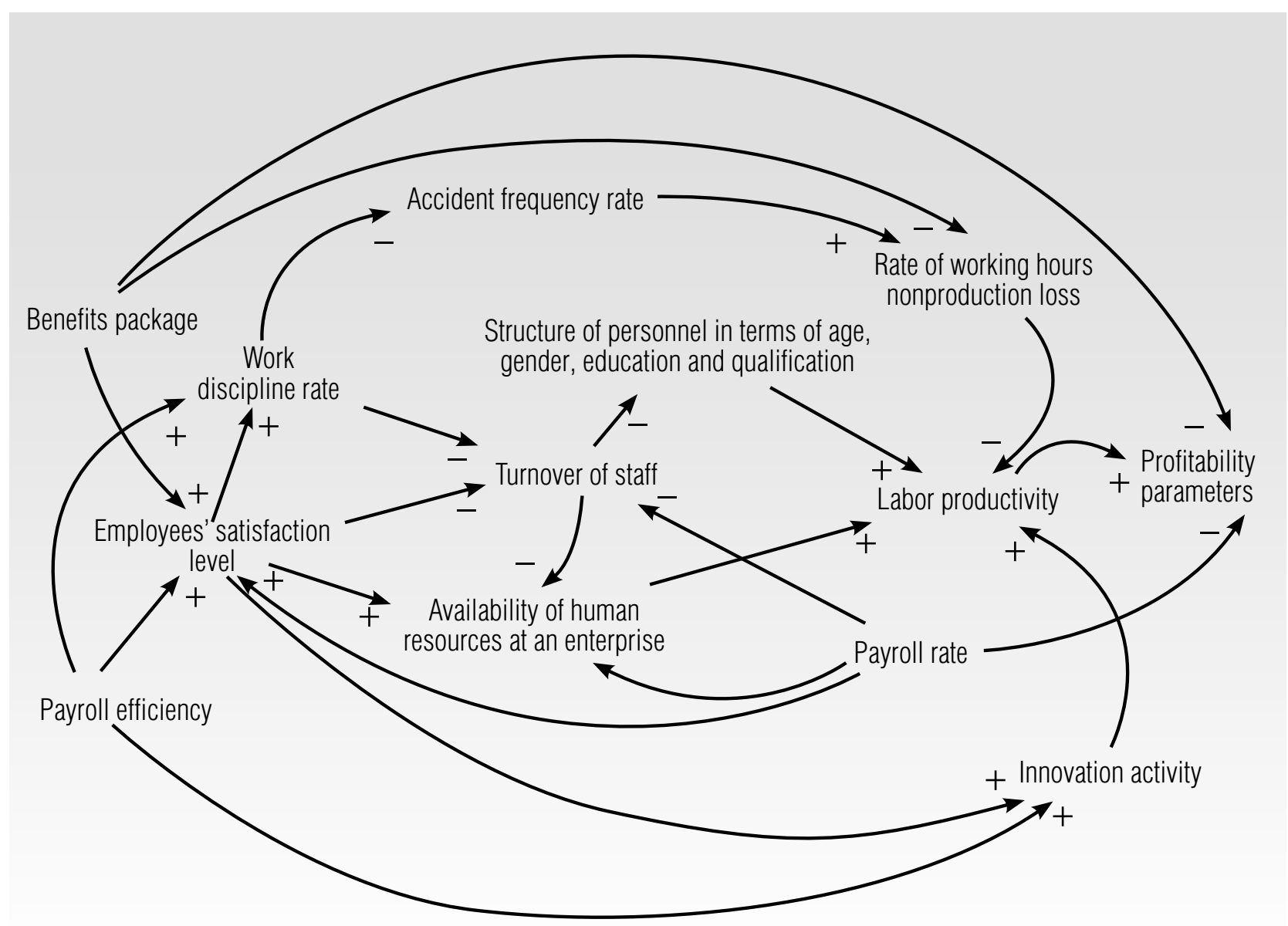

Fig. 1. Cognitive map of an enterprise's human resources management 
The cognitive map does not answer the question of how much quantitatively the profitability parameters will change in case of raising wages of employees, but it allows us to identify at the qualitative level the mechanisms which make up all other parameter responses to the salary increase. Unlike cognitive modeling having a qualitative character, the flow modeling allows quantitative forecasting of dynamics of the simulated object parameters both with and without certain managerial actions.

Within the overall issue of human resources management, this work reviews its particular aspect - the analysis of a company's nonproduction losses due to temporary disability of employees. The temporary disability of an employee is understood as his/her temporary inability to perform job duties because of health condition of either himself/herself or his/her family members. There may be singled out the following principal causes of temporary disability:

\ Employee's reporting sick due to newly or previously acquired disease. As a rule, such losses are more common with enterprises having either hazardous working conditions or predominantly female or older staff;

\ Employee's family member becoming sick which results in temporary absence due to nursing the sick family member. Such losses occur mostly at enterprises employing many women of reproductive age;

^ Workplace and home injuries happen more often with male employees at enterprises with higher level of danger or hazard.

As per the data by United Inter-departmental System of Information and Statistics (EMISS), the number of temporary disability cases in the RF is 60.2 per 100 employees, the average duration of disability is 12.7 days ( www.fedstat.ru). These numbers allow us to find out that worktime losses due to temporary disability of employees come to approximately $2-3 \%$ per annum, which poses a series of problems for companies:

1. While sick, an employee does not perform his/her job duties which company-wise results in underperformance versus production and sale plans. In this respect, seasonal infectious diseases are a particularly unfavorable factor, since they cause large-scale absences of employees from their working places.

2. Temporary disability caused by industrial accidents may lead to additional company expenses related to full or partial payment of medical treatment of the injured.

The temporary disability may be partially controlled by the enterprise. The management actions listed below may be singled out:
1. Prevention measures with regard to seasonal diseases, such as vaccination of employees to reduce the rate of seasonal infections.

2. Development of social and non-specific preventive care (assignment of health resort vouchers, distribution of multivitamins) to raise immunity and resistance of employees to various diseases;

3. Installation of indoor equipment to reduce aerial circulation of viruses and bacteria and restrict the spread of infectious diseases;

4. Labor safety and personnel training measures to reduce the industrial accident rate.

The flow model of assessing corporate losses caused by temporary staff disability is aimed at substantiating the organizational and managerial decisions in the human resources management. The primary focus is on temporary disability of employees during the intensive spread of seasonal viral infections.

\section{Description of the flow model assessing enterprise losses from staff's temporary disability}

\subsection{Purposes of the development}

1. Evaluation of an enterprise's nonproduction losses due to temporary disability of its employees.

2. Assessing the impact of managerial action on the size of enterprise nonproduction losses due to temporary disability of its employees.

\subsection{Basic assumptions of the model}

1. An employee's temporary disability may occur due to the following causes: seasonal infections; industrial accidents; other diseases. The temporary disability of an employee due to his/her family members' sickness is not addressed in the model.

2. The industrial accident rate is stable during the entire year, as well as the frequency of other diseases. Other diseases are considered non-infectious.

3. The seasonal infections rate is of a clear-cut seasonal nature. Infections are passed via contacts of the healthy with the infected. The contacts may occur both in the workplace and outside. The likeliness of contagion depends on the number of contacts a healthy employee has with infected colleagues and on the degree of infection spread outside.

4. The overall immunity rate is a variable value depending on the season. Absolute specific immunity develops after twice consecutively contracting a seasonal viral infection. 
It depends on the overall and specific immunity of an employee whether he/she gets infected or not.

5. The staff is permanent, i.e. nobody is dismissed or hired.

\subsection{A list of employee conditions from the point of view of working hour losses due to temporary disability of employees}

Pursuant to the model's objectives and assumptions, we determine a list of possible conditions of employees and the logic of transition from one condition to another.

An employee condition is described with the following sequence of data:

$$
S=(Z, I, V, R),
$$

where $Z$ - health condition;

$I$ - the condition of specific immunity to seasonal infections;

$V-$ the ability to infect healthy employees upon contact;

$R-$ disability.

Health conditions $(Z)$ may take the following values: $-Z_{1}-$ healthy, has never been ill with a seasonal infection; $-Z_{2}-$ got infected with a seasonal infection for the first time;

$-Z_{3}-$ got ill with a seasonal infection for the first time;

$-Z_{4}-$ is ill with a seasonal infection for the first time;

$-Z_{5}$ - healthy after being ill with a seasonal infection once;

$-Z_{6}-$ got infected with a seasonal infection for the second time;

$-Z_{7}-$ got ill with a seasonal infection for the second time,

$-Z_{8}-$ is ill with a seasonal infection for the second time;

$-Z_{9}$ - healthy after being ill with a seasonal infection twice;

$-Z_{10}-$ injured, has never been ill with a seasonal infection;

$-Z_{11}-$ sick with other diseases, has never been ill with a seasonal infection;

$-Z_{12}-$ injured, was ill with a seasonal infection once;

$-Z_{13}-$ sick with other diseases, was ill with a seasonal infection once;

$-Z_{14}$ - injured, was ill with a seasonal infection twice;

$-Z_{15}$ - sick with other diseases, was ill with a seasonal infection twice.

The condition of specific immunity to seasonal infections $(I)$ is related to the degree of social protection of employees. It may take the following values:

$-I_{0}-$ no specific immunity to a seasonal infection;
$-I_{1}-$ existing specific immunity to seasonal infections.

The ability to infect healthy employees by a contact $(V)$ is determined by organizational peculiarities of the working process and may take the following values:

$-V_{0}-$ not able to infect other employees;

$-V_{1}-$ able to infect other employees.

Disability $(R)$ may take the following values:

$-R_{0}-$ does not perform job duties,

$-R_{1}-$ performs job duties.

For the sake of brevity, we will designate the employee condition as $S_{z, i, v, r}$, where $z$ - the $Z$ value number, $i-$ the $I$ value number, $v$ - the $V$ value number, $r$ - the $R$ value number. For example, condition $S_{1,0,0,1}$ is described as: healthy, has not been sick with a seasonal infection; has no specific immunity to seasonal infection, not able to infect other employees, keeps performing job duties. Since the components specifying the employee's condition are not independent, not all of their combinations are possible. Let us list the possible conditions: $S_{1,0,0,1}$, $S_{2,0,0,1}, S_{3,0,1,1}, S_{4,0,0,0}, S_{5,0,0,1}, S_{6,0,0,1}, S_{7,0,1,1}, S_{8,0,0,0}, S_{9,1,0,1,}$ $S_{10,0,0,0}, S_{11,0,0,0}, S_{12,0,0,0}, S_{13,0,0,0}, S_{14,1,0,0}, S_{15,1,0,0}$. Thus, at any moment of time an employee may be in one of the 15 conditions.

The employee condition and transition graph is shown in Figure 2.

\subsection{Equations of the model}

The model equations use the following designations:

$L_{i}(t)$ - number of employees in an $i$-th condition $(i=1, \ldots, 15)$ at the $t$ moment of time;

$\lambda_{i, j}(t)$ - intensity of transition of employees from an $i$-th condition to a $j$-th condition;

$J_{i}^{-}$- set of indices of conditions in which there exists a transition from an $i$-th condition;

$J_{i}^{+}$- set of indices of conditions from which there exists a transition to an $i$-th condition.

Then the dynamics of staff number in various conditions is described with a system of 15 finite-difference equations of the following type:

$L_{i}(t+1)=L_{i}(t)-\sum_{j \in J_{i}} \lambda_{i, j}(t) \cdot L(t)+\sum_{j \in J_{i}^{+}} \lambda_{i, j}(t) \cdot L(t) .(1)$

The evaluation of an enterprise's losses from temporary disability of employees is built on the dynamics of number of employees in different conditions.

Enterprise losses $T$ (in man days) due to temporary disability of employees for an interval of time $\left(t_{1}, t_{2}\right)$ are calculated by formula (2): 


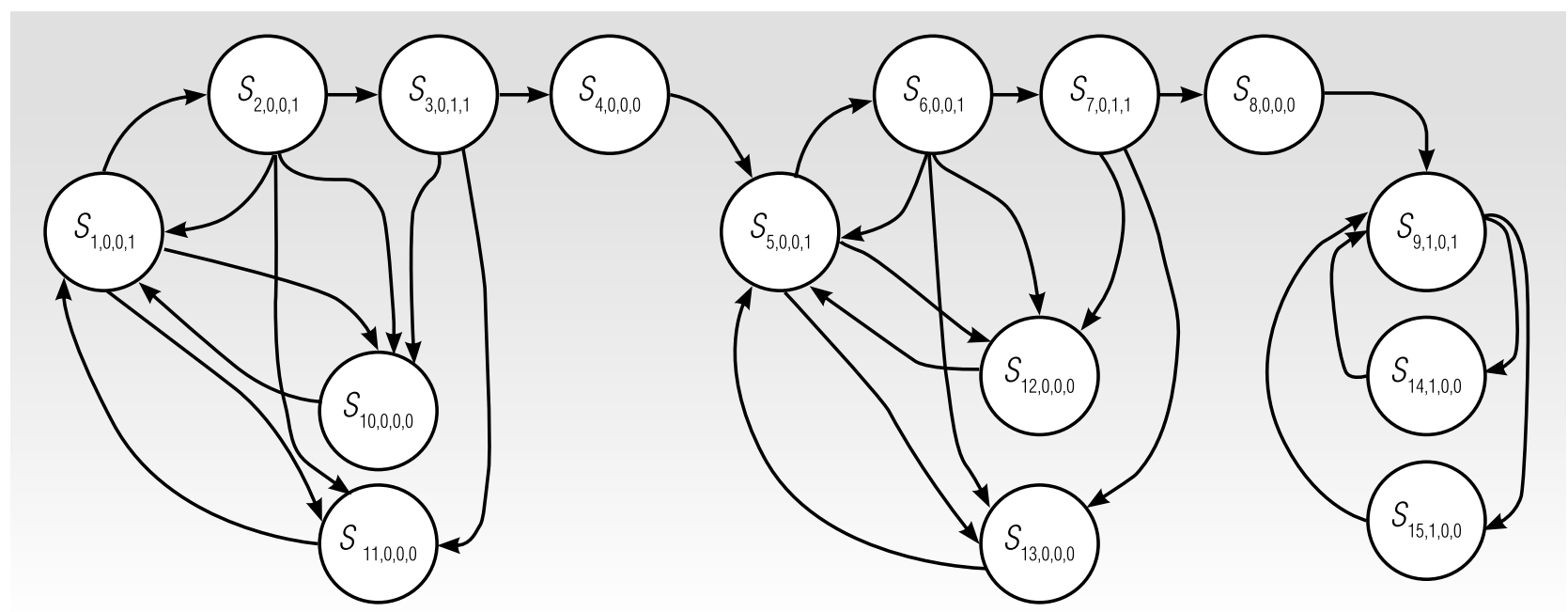

Fig. 2. Employee condition and transition graph

$$
T\left(t_{1}, t_{2}\right)=\sum_{t=t_{1}}^{t_{2}} \sum_{j \in J_{h}} L_{j}(t)
$$

In formula (2), $J_{n}$ is a set of indices of conditions where the employee is absent from work, $J_{n}=\{4,8,10,11,12$, $13,14,15\}$.

Accordingly, enterprise losses $D$ due to temporary disability of employees for an interval of time $\left(t_{1}, t_{2}\right)$ are calculated by the formula:

$$
D\left(t_{1}, t_{2}\right)=\bar{V} \cdot T\left(t_{1}, t_{2}\right) .
$$

In formula (3), $\bar{V}$ is the average labor productivity of the enterprise's employees. It is calculated as the ratio of the enterprise's annual receipts to the actually fulfilled man-days per year.

The intensity of transitions between conditions is determined with regard to intensity of disease spread.

$\lambda_{1,2}(t), \lambda_{5,6}(t)$ are the intensities of infecting healthy employees without immunity to seasonal viral infections. They are calculated by the formula:

$$
\lambda_{1,2}(t)=\lambda_{5,6}(t)=m \cdot\left(k_{1} \cdot p_{1}(t)+k_{2} \cdot p_{2}(t)\right) .
$$

Formula (4) uses the following designations:

$m$ - probability of infecting in case of contact with an infected or sick person at workplace or outside;

$k_{1}$ - average intensity of employee's contacts at workplace;

$p_{1}(t)$ - probability of a contact with an infected employee; it is determined as the ratio of infected employees to those capable of working, i.e. by the formula:

$p_{1}(t)=\frac{L_{3}(t)+L_{7}(t)}{L_{1}(t)+L_{2}(t)+L_{3}(t)+L_{5}(t)+L_{6}(t)+L_{7}(t)+L_{9}(t)}$, where $k_{2}$ - average intensity of employee's contacts with other people outside the workplace;

$p_{2}(t)-$ probability of contact with an infected or sick person outside the workplace. It is determined in accordance with the data on seasonal infection dynamics in the region.

The rest of intensities are constant values.

Intensities $\lambda_{2,1}$ and $\lambda_{6,5}$ are equal and are calculated by the formula:

$$
\lambda_{2,1}=\lambda_{6,5}=\frac{\operatorname{Im}}{\tau_{\text {in }}}-\lambda_{2,10}-\lambda_{2,11}
$$

Intensities $\lambda_{2,3}$ and $\lambda_{6,7}$ are also equal and are calculated by the formula:

$$
\lambda_{2,3}=\lambda_{6,7}=\frac{(1-\operatorname{Im})}{\tau_{i n}}-\lambda_{2,10}-\lambda_{2,11}
$$

In formulas (6) and (7), $\tau_{\text {in }}$ is the average duration of the infecting period; $I m$ is a number from 0 to 1 , reflecting the state of immunity of employees at an enterprise.

Intensities $\lambda_{10,1}, \lambda_{12,5}, \lambda_{14,9}$ are equal and are calculated by the formula:

$$
\lambda_{10,1}=\lambda_{12,5}=\lambda_{14,9}=\frac{1}{\tau_{t r}} .
$$

In formula (8), $\tau_{t r}$ is the average duration of an injured employee's sick leave.

Intensities $\lambda_{11,1}, \lambda_{13,5}, \lambda_{15,9}$ are equal and are calculated by the formula:

$$
\lambda_{11,1}=\lambda_{13,5}=\lambda_{15,9}=\frac{1}{\tau_{p b}} .
$$


The relationship between the parameters of the simulation and management impact

\begin{tabular}{|c|c|c|}
\hline $\begin{array}{l}\text { Management } \\
\text { targets }\end{array}$ & Management actions & $\begin{array}{l}\text { Simulation } \\
\text { parameters }\end{array}$ \\
\hline $\begin{array}{l}\text { Reducing susceptibility } \\
\text { of employees } \\
\text { to seasonal viral } \\
\text { infections }\end{array}$ & $\begin{array}{l}\text { - organizational and educational activity for the free vaccination of employees; } \\
\text { - the enrichment of nutrition with vitamins; } \\
\text { - providing preventive and curative services to employees in the medical departments of the } \\
\text { enterprise; } \\
\text { - full or partial payment of diagnostic, preventive, health services as a part of a social package } \\
\text { of enterprise }\end{array}$ & $m, I m$ \\
\hline $\begin{array}{l}\text { Impeding the spread } \\
\text { of infection }\end{array}$ & $\begin{array}{l}\text { - installation of equipment for air purification and ventilation in the premises of the enterprise; } \\
\text { - minimizing the number of meetings with the participation of a large number of employees in period } \\
\text { of active proliferation of seasonal viral infections; } \\
\text { - encouraging employees to take sick leave }\end{array}$ & $k_{1}, m$ \\
\hline $\begin{array}{l}\text { Reducing the overall } \\
\text { incidence among the } \\
\text { enterprise's employees }\end{array}$ & $\begin{array}{l}\text { - including voluntary health insurance programs in the social package of the enterprise; } \\
\text { - carrying out regular medical examinations of employees; } \\
\text { - equipping workplaces with equipment protecting against harmful environment factors; } \\
\text { - the enrichment of nutrition with vitamins }\end{array}$ & $\begin{array}{l}\lambda_{1,11}, \lambda_{2,11}, \lambda_{3,11} \\
\lambda_{5,13}, \lambda_{6,13}, \lambda_{7,13} \\
\lambda_{9,15}\end{array}$ \\
\hline $\begin{array}{l}\text { Reducing workplace } \\
\text { injuries }\end{array}$ & $\begin{array}{l}\text { - assessment of the workplaces; } \\
\text { - rational schedule of working day including special time for rest and nutrition; } \\
\text { - technical re-equipment of outdated production facilities, installation of protective screens, barriers }\end{array}$ & $\begin{array}{l}\lambda_{1,10}, \lambda_{2,10}, \lambda_{3,10} \\
\lambda_{5,12}, \lambda_{6,12}, \lambda_{7,12} \\
\lambda_{9,14}\end{array}$ \\
\hline
\end{tabular}

In formula (9), $\tau_{p b}$ is the average duration of a sick leave due to other diseases.

Intensities $\lambda_{3,4}, \lambda_{7,8}$ are equal and are calculated by the formula:

$$
\lambda_{3,4}=\lambda_{7,8}=\frac{1}{\tau_{z r}} .
$$

In formula (10), $\tau_{z r}$ is the average duration of infection period.

Intensities $\lambda_{4,5}, \lambda_{8,9}$ are equal and are calculated by the formula:

$$
\lambda_{4,5}=\lambda_{8,9}=\frac{1}{\tau_{s i}} .
$$

In formula (11), $\tau_{s i}$ is the average duration of a sick leave due to a seasonal infection.

The influence of management actions on the value of nonproduction losses from temporary disability of employees is measured through changing simulation parameters. The relationship between the parameters of the simulation and management impacts is given in Table 1 .

\section{Testing the model}

The model was tested in the Ufa Engine Industrial Association company, located in the Republic of Bashkortostan (www.umpo.ru). The purpose of the simulation was to evaluate the nonproduction losses of the enterprise associated with seasonal viral infections, as well as analysis of the effectiveness of management decisions aimed at reducing losses.

Ufa Engine Industrial Association is a large enterprise engaged in the development, production and after-sales service of gas-turbine engines for military aircraft. The number of employees exceeds 20,000. The enterprise is not classified as a company with hazardous working conditions. Since January 2006, a social package has been introduced, and the money may be used to pay for preventive and medical services, services of sports and fitness. Caring for the health of workers is an integral part of the social program of the enterprise. The company has its own recreation centers with services aimed at year-round recreation and health recovery of employees. 
An estimation of model parameters was carried out with the use of enterprise data, regional and industrial statistics as well as on the basis of analytical materials devoted to seasonal viral infections. The following settings were used: the time step is equal to 1 day, the unit for time is the Day, the initial time is equal to zero, the final time is equal to 365 . All simulation parameters were calculated according to the selected unit of measurement.

To assess such simulation parameters as the average time of incubation, the average time of infection, the average duration of sick leave due to the seasonal infection, the data of the websites of National Pulmonary Fund (www.legkie.org) and Influenza Research Institute (www.influenza.spb.ru) were used. According to these data, the incubation period for respiratory viral infection lasts from 1 to 3 days. The respiratory viral infection patient is most infectious to others for 2-3 days. Then the rate of viral replication in the body of the sick persons is greatly reduced, but the release of the virus into the environment may continue for up to 2 weeks. The total duration of respiratory viral infection is up to 14 days. However, most people recover in a period from 7 to 10 days. In this regard, in the calculations, the following values of the parameters were used: $\tau_{i n}=3$ days, $\tau_{z r}=2$ days, $\tau_{s i}=10$ days.

In order to estimate transition intensities to the states $S_{10,0,0,0}, S_{12,0,0,0}, S_{14,1,0,0}$ (the following parameters: $\lambda_{1,10}$, $\left.\lambda_{2,10}, \lambda_{3,10}, \lambda_{5,12}, \lambda_{6,12}, \lambda_{7,12}, \lambda_{9,14}\right)$ the data of the website of Federal State Statistic Service of Russian Federation (www.gks.ru) were used. According to these data, the average number of employees in the industry "Manufacture of machines and equipment" in the year 2015 was 781,031 people, the number of injured at work to incapacity for 1 day or more and with a fatal outcome was 1,369 people. Consequently, the intensities of the transitions in the states $S_{10,0,0,0}, S_{12,0,0,0}, S_{14,1,0,0}$ are equal to 0.0000048 . The number of man-days of disability of injured at work to incapacity for 1 day or more and with a fatal outcome is 62,179 . On this basis, the average duration of incapacity for work due to occupational injuries is 45.4 days (the parameter $\tau_{t r}$ ).

To assess transition intensities to the states $S_{11,0,0,0}$, $S_{13,0,0,0}, S_{15,1,0,0}$ (the following parameters: $\lambda_{1,11}, \lambda_{2,11}, \lambda_{3,11}$, $\left.\lambda_{5,13}, \lambda_{6,13}, \lambda_{7,13}, \lambda_{9,15}\right)$ the data on total incidence rates and temporary disability of the population of the Republic of Bashkortostan in the year 2015 were used as shown on the website of the Federal State Statistic Service of Russian Federation (www.gks.ru). On this basis, transi- tion intensities to the states $S_{11,0,0,0}, S_{13,0,0,0}, S_{15,1,0,0}$ in the simulation are equal to 0.000821 .

\section{Model implementation}

A flow model has been implemented in the VenSim PLE package (https://vensim.com). The advantages of this package which predetermined its choice as a modeling environment are: convenient intuitive interface, support both cognitive and flow modeling, free of charge for use in academic purposes, the ability to export simulation results.

As an example, let us see the results of two model simulations held to assess preventive measures aimed at raising the overall immunity of an enterprise's staff. The model parameter Im, which reflects the state of overall immunity of employees, was calculated by formula (12) in the first experiment and by formula (13) in the second:

$$
\begin{gathered}
I m=\left\{\begin{array}{c}
0.5 \text { from week } 36 \text { till week } 45 \\
0.53 \text { otherwise }
\end{array}\right. \\
I m=\left\{\begin{array}{c}
0.6 \text { from week } 36 \text { till week } 45 \\
0.63 \text { otherwise }
\end{array}\right.
\end{gathered}
$$

As can be seen from the formulas, the immunity rate in the second simulation is better than in the first, which reflects the influence of preventive measures. The immunity deterioration in the period from week 36 till week 45 in both experiments reflects a known biological pattern that, according to medical data, at that time (late winter - early spring) most of people have worse immunity than at any other time of year (www.influenza. spb.ru).

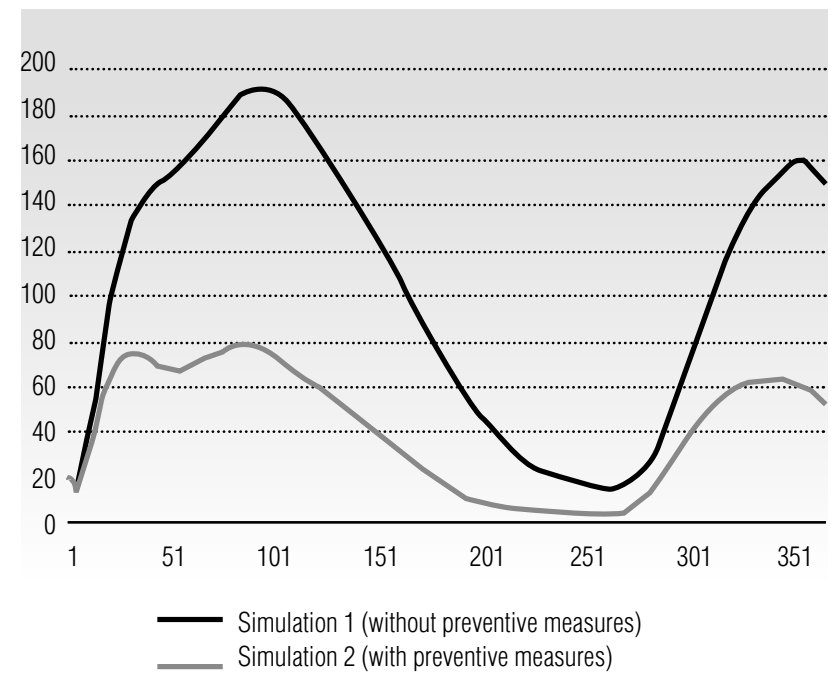

Fig. 3. Number of enterprise employees temporarily out of job duties because of a seasonal viral infection 
The rest of the parameters were the same in both simulations.

Figure 3 shows the dynamics of the number of an enterprise staff who are temporarily not performing their job duties because of falling ill to a seasonal viral infection.

As can be seen from Figure 3, preventive measures to raise overall immunity can significantly relieve the problem of massive absence from workplaces during seasonal viral epidemics.

\section{Conclusion}

Cognitive modeling is used in this work to structure the issue of human resources management at an en- terprise. Analysis of the cognitive map has shown that the parameters specifying human resources of an enterprise are connected by a significant number of direct and feedback links, both amplifying and counterbalancing ones. This predetermines the complexity of forecasting and assessing the efficiency of managerial decisions in human resources management.

This work offers a flow model which allows one to evaluate the nonproduction losses of an enterprise caused by temporary disability of its employees. It is shown that on the basis of this model it is possible to review the efficiency of managerial actions, such as vaccination of employees, non-specific prevention, installation of air treatment equipment, labor safety and efforts to improve work discipline.

\section{References}

1. Deconstructing the BRICs: Structural transformation and aggregate productivity growth / G.J. de Vries [et al.]. Journal of Comparative Economics, no. 40, pp. 211-227.

2. Vaisburd V.A., Simonova M.V., Bogatyreva I.V., Vanina E. G., Zheleznikova E.P. (2016) Productivity of labour and salaries in Russia: Problems and solutions. International Journal of Economics and Financial Issues, no. 6 (5), pp. $157-165$.

3. Lavrovskii B.L. (2015) Russian and world trends in productivity. Studies on Russian Economic Development, vol. 26, no. 3, pp. 278284.

4. Kardashevskiy V.V.,AmirovA.G. (2012) Proizvoditel'nost' truda:problemy i perspektivy razvitiya [Labour productivity: problemsand perspectives of development]. Labour Safety and Economics, no. 4 (9), pp. 81-88 (in Russian).

5. Chekmarev O.P.(2015) Motivatsiya povysheniya proizvoditel'nostitruda naemnykh rabotnikov: faktory defitsita kadrov, razmerai differentsiatsiioplaty truda [Employees motivation on increasing labourproductivity: deficit oflabourforce, wage size and differentiation]. Proceedings of Saint Petersburg State Agrarian University, no. 38, pp. 184-190 (in Russian).

6. Zolotov A.V., Mazur O.A., Popov M.V. (2015) Dynamics of labour input and average annual hours actually worked per worker in industry of developed countries and Russia: Similarities and differences. Asian Social Science, vol. 11, no. 14, pp. 205-210.

7. McKinsey Global Institute (2009) Effektivnaya Rossiya:proizvoditel'nost' kak fundament rosta [Effective Russia:labourproductivity as a basis of growth]. Russian Management Journal, vol. 7, no. 4, pp. 109-168 (in Russian).

8. Ismagilova L.A., Gileva T.A. (2006) Sotsial'nye investitsii v razvitie chelovecheskogo kapitala predpriyatiya: obosnovanie i otsenka [Social investments for human capital development: study and evaluation]. St. Petersburg State Polytechnical University Journal. Economics, no. 48-2, pp. 153-158 (in Russian).

9. Savitskaya G.V.(2016). Analizkhozyaystvennoy deyatel'nostipredpriyatiya [Analysis of economic activities of an enterprise]. Moscow: INFRA-M (in Russian).

10. Avdeeva Z.K., Kovriga S.V., Makarenko D.I., Maksimov V.I. (2007) Kognitivnyy podkhod v upravlenii [Cognitive approach in management]. Control Sciencies, no. 3, pp. 2-8 (in Russian).

11. Abramova N.A. (2007) O probleme riskov iz-za chelovecheskogo faktora v ekspertnykh metodakh i informatsionnykh tekhnologiyakh [The problem of the risks due to human factors in the expertise methods and information technologies]. Control Sciencies, no. 2, pp. 11-21 (in Russian).

12. Sterman J. (2000). Business dynamics: systems thinking and modeling for a complex world. McGraw-Hill.

13. Katalevskii D.Yu. (2015) Osnovy imitatsionnogo modelirovaniya i sistemnogo analiza v upravlenii [Fundamentals of management simulation modeling and system analysis]. Moscow: Delo, RANEPA (in Russian). 


\section{Динамическая модель оценки непроизводственных (трудовых) потерь предприятия}

\section{Л.А. Исмагилова}

доктор технических наук, профессор, заведующая кафедрой экономики предпринимательства Уфимский государственный авиационный технический университет Адрес: 450000, г. Уфа, ул. К. Маркса, д. 12

E-mail: Ismagilova_ugatu@mail.ru

\section{М.В. Франц}

кандидат технических наук, доцент кафедры экономики предпринимательства Уфимский государственный авиационный технический университет Адрес: 450000, г. Уфа, ул. К. Маркса, д. 12

E-mail:tan-Marina@mail.ru

\section{М.Б. Кульмухаметов}

аспирант, Институт соииально-экономических исследований Уфимский научный центр Российской академии наук Адрес: 450000, г. Уфа, проспект Октября, д. 71

E-mail: murat.kulmuhametov@gmail.com

\section{Аннотация}

Статья посвящена проблеме управления трудовыми ресурсами на предприятии. Трудовые ресурсы рассматриваются как динамический объект управления, характеризующийся большим количеством показателей, отражающих отдельные аспекты его состояния. Традиционные методики анализа трудовых ресурсов, во-первых, носят ретроспективный характер, а вовторых, рассматривают отдельные аспекты управления трудовыми ресурсами изолированно друг от друга. Предлагаемые управленческие решения оцениваются с точки зрения их влияния на отдельные показатели, но не оценивается их синергетический эффект. Для преодоления указанных недостатков предлагается использовать метод динамического моделирования, включающий когнитивное и потоковое моделирование.

Когнитивное моделирование позволяет идентифицировать механизмы, формирующие реакцию системы на управленческие и возмущающие воздействия. В работе представлена когнитивная карта проблемы управления трудовыми ресурсами, включающая значительное число усиливающих и уравновешивающих контуров обратных связей. Это означает, что рассматриваемый объект управления характеризуется такими свойствами, как нелинейность динамики и противоинтуитивность поведения. Описанные особенности обуславливают сложность прогнозирования его реакции на управленческие и возмущающие воздействия.

Также в работе в рамках общей проблемы управления трудовыми ресурсами рассматривается ее отдельный аспект - анализ непроизводственных потерь предприятия от временной нетрудоспособности работников. Под временной нетрудоспособностью работника понимается его неспособность временно исполнять трудовые обязательства в связи с состоянием здоровья или самого работника, или членов его семьи. Временная нетрудоспособность работников рассматривается как параметр, частично управляемый со стороны предприятия. В работе описана потоковая модель оценки непроизводственных потерь предприятия от временной нетрудоспособности его работников, в которой внимание фокусируется на временной нетрудоспособности работников в период активного распространения сезонных вирусных инфекций. Предложенная модель может быть использована для оптимизации затрат предприятия на управление трудовыми ресурсами с точки зрения соотношения затрат и результатов.

Ключевые слова: управление трудовыми ресурсами, динамическое моделирование, когнитивная карта, потоковое моделирование. 
Цитирование: Ismagilova L.A., Frants M.V., Kulmukhametov M.B. A dynamic model for assessing nonproduction (labor) losses of an enterprise // Business Informatics. 2017. No. 1 (39). P. 14-24. DOI: $10.17323 / 1998-0663.2017 .1 .14 .24$.

\section{Литература}

1. Deconstructing the BRICs: Structural transformation and aggregate productivity growth / G.J. de Vries [et al.] // Journal of Comparative Economics. 2012. No. 40. P. 211-227.

2. Productivity of labour and salaries in Russia: Problems and solutions / V.A. Vaisburd [et al.] // International Journal of Economics and Financial Issues. 2016. No. 6 (5). P. 157-165.

3. Lavrovskii B.L. Russian and world trends in productivity // Studies on Russian Economic Development. 2015. Vol. 26. No. 3. P. $278-284$.

4. Кардашевский В.В., Амиров А.Г. Производительность труда: проблемы и перспективы развития // Охрана и экономика труда. 2012. № 4 (9). С. 81-88.

5. Чекмарев О.П. Мотивация повышения производительности труда наемных работников: факторы дефицита кадров, размера и дифференциации оплаты труда // Известия Санкт-Петербургского государственного аграрного университета. 2015 . № 38. C. $184-190$.

6. Zolotov A.V., Mazur O.A., Popov M.V. Dynamics of labour input and average annual hours actually worked per worker in industry of developed countries and Russia: Similarities and differences // Asian Social Science. 2015. Vol. 11. No. 14. P. 205-210.

7. Эффективная Россия: производительность как фундамент роста / McKinsey Global Institute // Российский журнал менеджмента. 2009. T. 7. № 4. C. 109-168.

8. Исмагилова Л.А., Гилева Т.А. Социальные инвестиции в развитие человеческого капитала предприятия: обоснование и оценка // Научно-технические ведомости Санкт-Петербургского государственного политехнического университета. Экономические науки. 2006. № 48-2. С. 153-158.

9. Савицкая Г.В. Анализ хозяйственной деятельности предприятия: учебное пособие. Москва: ИНФРА-М, 2016.

10. Когнитивный подход в управлении / 3.К. Авдеева и [др.] // Проблемы управления. 2007. № 3. С. 2-8.

11. Абрамова Н.А. О проблеме рисков из-за человеческого фактора в экспертных методах и информационных технологиях // Проблемы управления. 2007. № 2. С. 11-21.

12. Sterman J. Business dynamics: systems thinking and modeling for a complex world. McGraw-Hill, 2000.

13. Каталевский Д.Ю. Основы имитационного моделирования и системного анализа в управлении: учебное пособие. М.: Дело, РАНХиГС, 2015. 